\title{
Cumhuriyet Halk Partisi Özelinde Filistin Sorunu
}

\author{
Palestine Problem within the Scope of Republican People's Party
}

\section{Selçuk ASLAN}

Öğr. Grv., Dumlupinar Üniversitesi, Gediz MYO,

selcuk.aslan@dpu.edu.tr

https://orcid.org/0000-0003-3916-331X

\section{Yusuf UYSAL}

Dr.Öğr.Üyesi., Dumlupinar Üniversitesi, Gediz MYO,

yusuf.uysal@dpu.edu.tr

https://orcid.org/0000-0003-3872-3119
Makale Başvuru Tarihi: 24.07.2019

Makale Kabul Tarihi: 25.09.2019

Makale Türü: Araştırma Makalesi

\section{ÖZET}

\section{Anahtar \\ Kelimeler: \\ Cumhuriyet Halk \\ Partisi,}

Filistin,

Israil,

Filistin Sorunu,

Orta Doğu,

Keywords:

Republican People's

Party,

Palestine,

Israel,

Palestine Question,

Middle East,
Filistin; dini, siyasi ve kültürel açıdan taşıdı̆̆ anlamı, Doğu Akdeniz'de yer alan tarifsiz jeopolitik konumu ve Kudüs şehrinin üç din açısından ehemmiyetli oluşuyla bölgede önemli bir yere sahip olmuştur. İkinci Dünya Savaşının bitmesi ve İsrail Devleti'nin kurulması ile birlikte Filistin'de yaşanan olaylar sadece bölgedeki devletlerin değil uluslararası alandaki bütün büyük devletlerin müdahil olduğu bir sorun haline gelmiștir. Günümüzde halen bu sorunun birçok devletin müdahil olmasına rağmen bir çözüme kavuşmaması aslında Filistin Sorununun karmaşıklı̆̆ının göstergesidir. Türkiye'nin dış politikası ne kadar Batı'ya dönük olsa da, Orta Doğu ile tarihsel, coğrafi, kültürel ve ekonomik bağları, Türkiye'yi bölge meseleleriyle ilgilenme gerekliliğiyle karşı karşılya bırakmıştır. Orta Doğuda bahsi geçen sorunların başında gelen Filistin Sorunu da Türkiye için özel bir konuma sahip olmuştur. Osmanll Devleti'nin Filistin'de uzun süre hâkimiyetinin olması ve Türk halkının Filistin'deki kutsal mekânlarla manevi bağının olması Türkiye'nin sorunla ilgilenmesinin tarihi ve kültürel sebeplerini oluşturmaktadır. Bu çalışmanın amacı, CHP'nin Filistin sorununa yaklaşımının tespit edilmesi ve sorunun çözümü için Partinin benimsediği politika ve görüşlerin saptanmasıdır. Bu bağlamda, dönemin dış ilişkilerden sorumlu CHP Genel Başkan Yardımcısı ve Şalom Gazetesi Köşe Yazarl ile görüşme yapılarak birincil veri toplama yöntemlerinden olan "görüşme" yöntemi kullanılmışıtır. Ayrıca konu ile ilgili ikincil kaynak taraması yapılmış ve veriler toplanmıştır.

\section{ABSTRACT}

Palestine has an important place in the region with its religious, political and cultural meaning, its important geopolitical position in the Eastern Mediterranean and the importance of the city of Jerusalem for three religions. With the end of the Second World War and the establishment of the State of Israel, the events in Palestine became a problem that involved not only the states in the region but all the major states in the international arena. The fact that this problem is still not solved despite the involvement of many states is an indication of the complexity of the Palestinian Question. Although Turkey's foreign policy focused on the West, with historical, geographical, cultural and economic ties, Turkey was required to deal with the issues of the Middle East also. Palestinian question, one of the most important problems in the Middle East has had a special position for Turkey. Long period of sovereignty of the Ottoman Empire had in Palestine and the spiritual connection of the Turkish people with the holy places in Palestine caused Turkey's dealing with question. The aim of this study is to determine the approach of RPP (Republican People's Party) to the Palestine issue and to observe the policies and visions of the party for solving the problem. In this context, face to face interview method, which is one of the primary data collection methods, has ben used by making interviews with the Vice Chairman of RPP and a Columnist of Şalom Newspaper. In addition, secondary literature review has been made on the subject and data has been gathered. 


\section{GÍRIŞ}

Günümüzde bir Türkiye Cumhuriyeti devletinden bahsediliyorsa, aslında aynı zamanda CHP'den bahsediliyor denmektedir. Zira CHP Türkiye Cumhuriyetini kurduğu gibi onu günümüze kadar getiren kimliği de temsil etmektedir veya temsil ettiği düşünülmektedir. Bir diğer ifade ile CHP devleti kuran partidir ve devletin temel ilkeleri olarak belirlenen Altı Ok'u temsil etmektedir. Cumhuriyet'in ve laikliğin Türkiye'deki bekçisi ve garantisidir. Devletin kurucu kadroları CHP içerisinden çıtığı için uzunca bir dönem CHP'nin sahip olduğu politik vizyon devletin siyasi vizyonu ile de eş değer tutulmuştur.

Elbette CHP'nin politik vizyonunun aynı zamanda devletin siyasi vizyonu olarak kabul edilmesi yaklaşımı Türkiye Cumhuriyeti’nin bir asra yakın tarihi boyunca süreklilik arz etmemiştir. Başka bir deyişle, CHP 27 yıl boyunca ülkeyi tek başına yönetmiş fakat daha sonra muhalefete düşmüştür. Bu düşüşten sonra CHP'nin iktidara hükümet ortağı olarak gelmesi istisnai birkaç durum dışında neredeyse hiç görülmemiştir. Tek başına iktidar ise hiç olamamıştır.

CHP her ne kadar Cumhuriyet Devletinin kurucu iradesi olarak ortadoğu'da önemli rol oynamış olsa da süreç içerisinde giderek bu coğrafyadan uzaklaşma eğilimine göstermiştir. Nitekim Bozdağlıoğlu, Ortadoğu coğrafyasında yaşanan gelişmelere karşı Türkiye Cumhuriyeti'nin temel duruşunun CHP tarafindan belirlendiğini ancak CHP tarafından ortaya konulan yeni kimlik kodları ve değerleri doğrultusunda Türkiye'nin Ortadoğu'dan uzaklaştığını belirtmektedir (Bozdağlıoğlu, 2003:115-43). Sander, bu uzaklaşmada rol oynayan en önemli etkenin Türkiye'nin kendisini tanımlamasında hiçbir şekilde Ortadoğu toplumları ile ortak bir noktada buluşmaması olduğunu ifade etmektedir. Yine Sander (1998) Ortadoğu toplumlarının yüzyılın başında kendilerini Arap ve İslam kimliği üzerinden tanımlarken Türkiye'nin kendisini batılı değerler ve laiklik üzerinden tanımladığını ifade etmektedir. CHP tarafından belirlenen bu Türk ulusal kimlik kodlarının, Ortadoğu toplumlarının kendilerini tanımladıkları milli kimlik anlayışıyla temel birleştirici unsurlardan yoksun olması Türkiye'nin Ortadoğu'dan soğumasının temel sebebi olarak görülmektedir (Sander, 1998:213).

Günümüzde Filistin sorunu olarak bilinen meselenin ortaya çıkması Türkiye'de CHP'nin iktidarı dönemine rastlamaktadır. Bu nedenle, Filistin sorunuyla ilk karşılaşan CHP iktidarı olmuştur. İslam ülkelerinin tepkisine yol açan ve İsrail devletini tanımadıkları bir dönemde kurulan devleti bölgede tanıyan ilk Müslüman ülke CHP yönetimindeki Türkiye Cumhuriyeti olmuştur. CHP'nin belirlemiş olduğu bu siyaset, elbette gelecek dönemlerde değişik siyasi partiler yönetiminde bir takım farklılıklar göstermiştir. Fakat CHP'nin pozisyonu uzun süre değişmemiştir.

Tüm bu bilgiler ışığında; günümüzde islam dünyası başta olmak üzere dünya kamuoyunu meşgul eden ve bölgenin önemli sorunlarından biri olarak Filistin sorununu temelde ve doğru olarak kavrayabilmek için Türkiye Cumhuriyeti'nin kurucu partisi CHP'nin Filistin sorununa bakışı önem arz etmektedir. Bu çerçeveden CHP'nin Filistin sorununa yaklaşımını hangi ideolojik anlayış belirlemiştir? Geçen süre içerisinde CHP'nin Filistin sorununa yaklaşımı nasıl olmuştur ve herhangi bir kırılma yaşanmış mıdır? CHP gerek kendi yönetimi ve gerekse muhalefet olduğu dönemde İsrail ile olan ilişkileri veya Türkiye'nin İsrail ile olan ilişkilerinde nasıl bir duruşa sahip olmuştur? Gelecekte Filistin sorununun çözülmesinde CHP geçmiş tecrübeler 1şığında nasıl bir rol üstlenebilir veya gerçekten bir rol üstlenebilir mi? Bu çalışmada bu sorulara cevap aranacak ve Türkiye'nin kurucu partisi CHP'nin Filistin meselesine yaklaşımı üzerinde durulacaktır.

\section{ANADOLU VE RUMELİ MÜDAFAA-İ HUKUK CEMIYETI'NDEN HALK FIRKASINA PARTİ TARIHI}

30 Ekim 1918 tarihinde Mondros Ateşkes Antlaşması'nın imzalanmasından sonra Trakya'da ve Anadolu'nun birçok şehrinde farklı isimlerde çok sayıda yerel direniş cemiyetleri kurulmuştur (Kılıç, 2011:30). 15 Mayıs 1919 tarihinde Yunanlıların İzmir'e ayak basması, Mustafa Kemal'in 19 Mayıs 1919'da Samsun'a çıkışı, bu cemiyetlerin bölgesel örgütlenmeden ulusal örgütlenmeye geçişince büyük bir rol oynamıştır (Kılıç, 2006:46). Direnişin Anadolu'ya hakim olmasından sonra ilk olarak Erzurum Kongresi ve akabinde Sivas Kongresi yapılmıştır. Sivas Kongresi ile Anadolu'daki dağınık direniş hareketleri bir çatı altında toplanmış, birleştirilen cemiyetlerin adı Sivas'ta toplanan millî bir kongrenin amacına ve yurt genelinde gerçekleştirilecek mücadelenin ruhuyla örtüşecek şekilde Anadolu ve Rumeli Müdafaa-i Hukuk Cemiyeti olarak değiştirilmiştir (Aydın, 2014:104-105). Sivas Kongresinin CHP acısından önemini Bila şöyle ifade etmektedir:

“Sivas Kongresi, Chp’nin 1. Kurultayı'dır. İlk kez bu kongrede ülkenin çeşitli bölgelerini temsilen gelen delegeler yasama ve yürütmeye yönelik kararlar almuş ve bir devlet kurma girişimlerinin en 
büyük adımlarını atmışlardır. Devlet kuran parti CHP, ilk kez bu kongrede filizlenmeye başlamıştır" (Bila, 1999:14-15).

1919 yılında yapılan genel seçimlere Anadolu ve Rumeli Müdafaa-i Hukuk Cemiyeti de katılmış ve büyük bir başarı elde ederek seçimleri kazanmıştır (Kılıç, 2006:49). Bu seçimlerden kısa bir süre sonra, 15 Mart 1920'de, İngilizlerin İstanbul'u işgal etmesi ve hemen ertesi gün meclise baskın yapıp bazı mebusları tutuklanması bazılarının da Anadolu'ya firar etmesi üzerine meclis 11 Nisan 1920'de feshedilmiş ve böylece yeni bir seçimin yolu açılmıştır (Derindere, 1999). Yapılacak bu yeni seçimin diğer seçimlerden farkı bulunmaktadır. 1920 yılında gerçekleşecek bu seçim normal bir parlamento seçimi olmamıştır. Bir başka ifade ile önceden kurulmuş olan bir meclise üye seçmek için yapılmış bir seçim değildir; çünkü seçimlerin yapıldığı zaman İstanbul işgal altında olduğu için hukuken de fiilen de bir meclisten bahsetmek mümkün değildir. Bu koşullar altında 19 Mart 1920 tarihinde bir tebliğ yayınlanmış ve seçimler buna göre yapılmıştır. Bu seçim sonunda 23 Nisan 1920'de Büyük Millet Meclisi açılmıştır (Armağan, 1967:66). Meclisin açıldıktan sonra önceleri milletvekilleri arasında tam bir mütabakat olsa da zamanla mecliste ortaklaşa bir çalışmanın sağlanıp düzenlemesinde güçlükler yaşanmaya başlanmıştır. Olağanüstü şartların yaşandığı dönemde Meclis iş göremez hale gelmiştir. Bu duruma çare olsun diye 1920'li yılların ortalarında bir takım gruplar oluşturulmuştur. Oluşturulan bu gruplar amacına ulaşmayınca Mustafa Kemal Paşa mecliste birlik ve beraberliği sağlamak için 10 Mayıs 1921'de Anadolu ve Rumeli Müdafaa-i Hukuk Grubu'nu kurmuştur (Aydın, 2014:114).

Eylül 1922'de İzmir'in Kurtuluşu ile özellikle Mustafa Kemal'in meclisteki konumu güçlenmiştir. Mustafa Kemal ‘e göre Anadolu ve Rumeli Müdafaa-i Hukuk Cemiyeti’nin ulusal kurtuluş mücadelesinde önemli bir rol oynamasına karşın barış ve bağımsızlığa ulaşmış bir ülke için yeterli değildi (Kılıç, 2006:69). Bunun için bu yapılanmayı siyasi parti haline getirmek için çalışmalara başlamış, 6.12.1922 tarihinde Hakimiyeti Milliye ve Yenigün Ögüt gazetelerine şu açıklamayı yapmıştır: “....sulhun istikrarını müteakip halkçılık esası üzerine müstenit ve Halk Firkası namiyle siyasi bir firka teşkil etmek niyetindeyim" (Atatürk Araştırma Merkezi, 2006:268). Mustafa Kemal bu tarihten sonra birçok yurt gezisinde Halkçılık esasına dayalı Halk Fırkası'nı kurmak istediğini dile getirmiştir (Atatürk Araştırma Merkezi, 2006:268-271-275-277).

1 Nisan 1923'te Meclis erken seçime gidilmesi kararı alındıktan 1 hafta sonra 8 Nisan 1923 tarihinde Mustafa Kemal yapılacak seçimlerle ilgili "9 Umde" adı verilen daha sonra da Halk Fırkası'nın Nizamnamesi'nin temelini oluşturacak bir beyanname yayınlamıştır (Çelik, 2004:50). 28 Haziran 1923 tarihinde yapılan seçimi I. Grup olarak adlandırılan Anadolu ve Rumeli Müdafaa-i Hukuk Grubu'nun kazanması üzerine Halk Fırkası hakkında görüşmek üzere 7 Ağustos 1923 tarihinde milletvekilleri mecliste toplanmış ve 8 Ağustos 1923 tarihli toplantıda Mustafa Kemal Halk Partisinin kurulmasının gerekliliğini uzunca dile getirmiştir. Günlerce devam eden toplantılar sonunda hazırlanan parti tüzüğü (Halk Fırkası Nizamnamesi) 9 Eylül 1923'te kabul edilerek Halk Fırkası resmen kurulmuştur (Kumaş, 1999:15). Halk Fırkası, cumhuriyetin ilanından sonra 10 Kasım 1924 yılında "Cumhuriyet Halk Fırkası", 1935 yılında ise "Cumhuriyet Halk Partisi” adını almıştır.

\subsection{Partinin İdeolojisi ve Siyasi Eğilimi}

CHP'nin ideolojisini dönemler halinde ifade etmek, partinin ideolojisinde meydana gelen değişimi görmek için en doğru yöntem olacaktır. İlk olarak “Tek Parti” döneminde CHP'nin ana felsefesi iki temele dayanmıştır. Bu iki temelden ilki, devleti kurtaran Müdafaa-i Hukuk özünden gelme; ikincisi ise, toplumun her kesimini temsil etmedir. Bu iki temel üzerine kurulmuş olan CHP için bu dönem, bir "halk partisi" olarak, çağdaşlaşma devrimlerinin gerçekleştirildiği ve çok partili rejime geçiş için temellerin atıldığ 1 bir dönem olmuştur (https://www.chp.org.tr/haberler/chp-tarihi). Bu dönemin CHP'si "solda" bir "tek parti” idi ama solculuğu komünizmden uzak, ancak sosyal demokrasiden daha da uzaktı (Güvenç, 2002:135).

Partinin ideolojisinde meydana gelen ilk değişim örneği 1959 yılında gerçekleştirilen 14.Büyük Kurultay'da kabul edilen "ilk Hedefler Bildirgesi" olmuştur. Bu bildirge ile CHP siyasal alanda devletçilikten biraz uzaklaşarak daha özgürlükçü ve liberal bir çizgiye kaymıştır (Örmeci, 2012).

1961 yılında sol bir parti olan Türkiye İşçi Partisi’nin (TIP) kurulması ve özellikle üniversite gençlerinin bu partiye sempati duyması CHP'yi yeni açlımlara yönlendirmiştir (Çelik, 2004:75) Ayrıca Avrupa'nın Sosyal Demokrasisi de CHP'nin ekonomik ve sosyal sorunlara bakışını etkilemeye başlamıştır. 1965 seçimleri öncesinde solun ve işçi hareketinin yarattığ 1 bask1 da CHP'yi tutumunu netleştirmeye zorlamıştır (Emre, 2013:77-78). 1965 yılına gelindiğinde İsmet İnönü ilk kez "Ortanın Solu” ifadesini kullanmıştır. Ancak kavram belli bir CHP'li grup tarafindan kabul görmemiştir. Sebebi ise, bu dönemde Türkiye'de sol eğilimlerin güç kazanması ve CHP'nin daha radikal, reformist ve sol seçmenlerini TíP'e kaptırması ihtimalinin olmasıdır. Bu 
baskılar partiyi sol eğilime kaydırmıştır. Ancak partinin esasında komünizm ideolojisiyle uzaktan yakından ilişkisi bulunmamasına rağamen sosyal ve siyasal ortam ve Adalet Partisi'nin (AP) kendilerini komünizm ile bağdaştırmasının önüne geçebilmek amacıyla CHP'yi ortanın solu kavramını kullanmaya zorlamıştır.

Burada önemli olan nokta şudur; günümüzde CHP'yi Ortadoğu'dan soyutlaştıran, uzaklaştıran süreç “ortanın solu" kavramının ortaya çıktığı dönemden itibaren başladığı ifade edilebilir. Çünkü artık bu dönemle birlikte, sol kimliğinin daha belirgin ve ağır basması ve Avrupa'dan etkilenmiş olması CHP'yi daha da Batılılaşmaya yönlendirmiştir.

"Ortanın Solu" kavramın mimarı Bülent Ecevit'in genel başkan olmasıyla birlikte CHP "Ortanın Solu"ndan "Demokratik Sol" tanımlamasına geçilmiştir. Sosyal demokrasi yerine demokratik sol deyiminin kullanılmasının sebebi, Rusya'da 17 Ekim Devrimi’ni gerçekleştiren partinin çok yerde adının Sosyal Demokrat Parti olarak anılması gösterilebilir. Diğer bir ifade ile 17 Ekim Rus Devrimi Sosyal demokrasi ve onun siyasi örgütlü partisi ile anılır olmasıCHP'yi “demokratik sol” kavramını kullanmaya sevk etmiştir (Bila, 1999:88). 1977 yılında Sosyalist Enternasyonel üyesi olan CHP'nin sosyal demokrat kimliği daha da derinleşmiştir (Önkaş, 2006:81). CHP'de kendisini tanımlama ile ilgili olarak yaşanan bu değişimlerin asıl sebebi aslında devlet partisi olmaktan giderek bir halk partisi durumuna gelmesidir. Merkezi devleti temsil eden bir partiden toplumun, halkın, sivil tercihlerin partisi olmaya yönelmesidir. CHP'nin bu süreci yaşarken gözden kaçırdığı ya da ihmal ettiği önemli bir nokta kendi içindeki muhafazakar kesimi göz ardı etmesi, esas olarak Türkiye'de hala önemli bir kitlenin muhafazakar olduğunu görememesidir. Ayrıca CHP'nin Türkiye'nin laik, seküler bir devlet olmasının halkın da bu yönde bir değişim geçirdiği, sekülerleştiği ve laikleştiği yönünde hakim bir görüşe sahip bulunmasıdır.

1980 darbesiyle kapatılan 1992 yılında tekrar açılan CHP, ideolojisinin temelini şu üç kaynaktan aldığını ifade etmektedir (CHP, 2004:69);

- Kemalizm

- Sosyal Demokrasinin Evrensel Değerleri

- Türkiye'nin Gerçekleri

Yeniden faaliyetlerine başlayan CHP 1992'de genel başkan olan Deniz Baykal'ın "Anadolu'nun Solu" kavramıyla yeni bir başlangıç yapmış kabul edilebilir. Bununla Baykal, milli-manevi değerlere saygılı söylem ve eylemleriyle partiyi sadece belli bir mezhep ya da etnik grubun partisi gibi algilanmaktan kurtarmay1 hedeflemiştir (Örmeci, 2012). 2006 yılında CHP Meclis Grubu'nda konuşan Deniz Baykal "Íster liberal ol, ister muhafazakâr, ister sağcı ol ister solcu. Içinde Atatürkçü laik Türkiye Cumhuriyeti'ne karşı sorumluluk duygusu olan tüm vatandaşlarımızı sorumluluk üstlenmek üzere CHP'ye çağırıyorum" sözleriyle esasında bu dönemde CHP'nin merkez sağa açıldığı belirtilmektedir (http://www.hurriyet.com.tr/mevlana-gibi-seslendi-gel-neolursan-ol-gel-4501053).

Aynı anlama gelen ancak farklı dönemlerde farklı ideolojik kavramlarla Türk Siyasal yaşamındaki yerini koruyan CHP'de Kemal Kılıçdaroğlu'nun genel başkan olmasıyla birlikte geçmişten günümüze devam eden siyasal duruş değişmemiş̧tir. Çünkü CHP “...kadın erkek eşitliğine inanan; bu değerleri gerçekleştirmeyi hedefleyen; devleti, kişilerin özgürlüklerini ve refahını sağlamaya yönelik bir hizmet aracı olarak kabul eden çağdaş demokratik sol bir siyasal parti” olarak dünden bu güne çizgisini korumaktadır (CHP, 1923:8).

\subsection{Partinin Tarihsel Süreç İçerisindeki Dönüm Noktaları}

Cumhuriyet Halk Partisi, Cumhuriyet ile yaşıt bir partidir. Bu tarihsel ve siyasal bağdan dolayı CHP Türkiye siyasal hayatında yaşanan kırılmalardan etkilenmiş, bu kırılmalara paralel veya karşııt tepkiler vermiştir (Övür, 2011:3). Partinin siyasi eğilimi ve ideolojisinden bahsederken de ifade edildiği üzere CHP her sancilı döneminde bir değişim içine girmiştir. CHP için önemli kırılma dönemleri şu başlıklar altında toplanabilir:

- Dörtlü Takrir: 7 Haziran 1945'de CHP'li 4 milletvekilinin, parti meclis grubunda açık olarak görüşülmek üzere, meclis grup başkanlığına verdikleri önergedir (Zenginoğlu, 2012). Bu önergeyi veren Celal Bayar, Adnan Menderes, Fuat Köprülü ve Refik Koraltan 2. Dünya Savaşı'nın bitmesinden sonra köylülerin ve aydınların demokrasiye hazır hale geldiklerinden dolayı millet meclisinin hükümeti fiilen kontrol etmesini, kişiye anayasada yazılı hak ve hürriyetlerin tanınmasını ve birden fazla partiye dayanan siyasi faaliyetlerin gelişmesine müsaade edilmesini istiyorlardı. Ayrıca basın kanunu ve polis kanununda değişiklik yapılmasını, gazete kapatma yetkisinin bakanlar kurulu yerine mahkemelere verilmesi 
savunuluyorlardı (Akbalık, 2006:40). Bu önerge reddedilse de CHP tarihinde parti içinde ilk kez yazılı bir belge ile muhalefet olan bir grup çıkmıştır.

- 1950 Seçimleri: Demokrat Parti'nin (DP) kurulmasından sonra gerçekleşen 1946 seçimlerinde CHP iktidar parti olmuştu. CHP bu başarının devam etmesini beklerken 14 Mayıs 1950 tarihinde gerçekleşen seçimlerde DP \%55.2 oy alarak iktidar olmuş, CHP ise \%39,6 oy alarak ana muhalefet partisi olmuştur (www.ysk.gov.tr). Bu seçimle birlikte CHP bir daha tek başına iktidar olamamıştır.

- 1961 Seçimleri: 27 Mayıs 1960 darbesinden sonra 15 Ekim 1961 tarihinde gerçekleşen seçimde CHP oyların \%36,7'sini alarak meclise 173 milletvekili gönderebilmiştir (www.ysk.gov.tr). Meclis’teki 450 milletvekili sayısının salt çoğunluğunu elde edemediğinden tek başına iktidar olamayan CHP, oyların \%34,8'ini alan Adalet Partisi ile Türkiye'nin ilk koalisyon hükümetini 20 Kasım 1961 tarihinde kurmuştur (Tuncer, 2012:6).

- İsmet İnönü’nün İstifası: 1971 Muhtırası sonrasında partisinin askeri yönetimce oluşturulan hükümete katkıda bulunmasına karşı çıkan ve askeri müdahaleyi Yunanistan modeline benzeten CHP Genel Sekreteri Bülent Ecevit 21 Mart 1971'de görevinden istifa etmiştir (Milliyet Gazetesi, 22.03.1971). Bu gelişmeden sonra parti içinde mücadelenin daha belirgin bir hal alması üzerine, bu mücadelenin çözümü amacıyla 5 Mayıs 1972 tarihinde 5.Olağanüstü Kurultay yapılmıştır. Gündeme göre parti meclisi için güven oylaması yapılmalıdır. İnönü parti meclisine güvenoyu verilmemesini, Ecevit ise güvenoyu verilmesini istemekteydi. Yapılan oylama sonucunda parti meclisi 1212 delegenin 709 oyuyla güven almıştır (Milliyet Gazetesi, 08.05.1972). Bu sonuçlar üzerine İsmet İnönü 34 yıllık CHP genel başkanlığından istifa etmiş (Milliyet Gazetesi, 09.05.1972), yerine 14 Mayıs 1972'de Bülent Ecevit seçilmiştir (Milliyet Gazetesi, 15.05.1972). Böylece CHP'de bir devir kapanıp bir devir başlamıştır.

- CHP'nin Kapatılması: 12 Eylül 1980 tarihinde Türk Silahlı Kuvvetlerinin ülke yönetimine el koymasıyla parlamento feshedilmiş, siyasi parti faaliyetleri de yasaklanmıştır (www.cnnturk.com). 28 Ekim 1980 tarihinde yabancı basın mensuplarına verdiği cevapların yanlış anlaşıldığı için Bülent Ecevit 30 Kasım 1980 tarihinde CHP genel başkanlığından istifa etmiştir (Milliyet Gazetesi, 31.10.1980). 16 Ekim 1981 tarihinde siyasi partilerin kapatılmasına ilişkin yasa yayınlanmış ve tüm siyasi partiler kapatılmıştır (Kültürel Yapılanma Grubu, t.y.:41). Bu gelişme 58 yıl faaliyet gösteren CHP'nin de kapatılması anlamına gelmekteydi.

- CHP’nin Yeniden Açılması: 19 Haziran 1992 yılında, DYP-SHP koalisyon hükümeti döneminde, 12 Eylül yönetimince kapatılan partilerin yeniden açılmasını sağlayan yasa kabul edildikten sonra (www.tbmm.gov.tr), CHP kurulduğu gün olan 9 Eylül'de yaptığı kongrede aynı ad ve amblemle açılmıştır. Yapılan oylamada Deniz Baykal genel başkan seçilmiştir (https://www.chp.org.tr/haberler/chp-tarihi).

\subsection{Partinin Dıș Politika Vizyonu}

Cumhuriyet Halk Partisi 2015 Seçim Bildirgesi’nde Dış Politikasının dayandığı temel ilkeleri şöyle açıklamıştır:

- "Yurttaş Merkezli Dış Politika": Bu ilke ile dış politikada öncelik yurttaşların güvenliğini, huzurunu ve refahını sağlamak olduğu; CHP'nin iktidarında devletin, yurttaşlarının canını tehlikeye atmayacağı, dünyanın neresinde olursa olsun yurttaşlarına güven vereceği ifade edilmiştir.

- "Değerleri Temel Alan Dış Politika": Bu değerlerin kaynağının Cumhuriyetin tarihinde ve sosyal demokrasinde mevcut olduğu dile getirilmiştir. Ayrıca insan haklarının güçlendirilmesi için uluslararası örgütler ve sivil toplum örgütleri ile iş birliği içinde çalışacağı da belirtilmiş̧ir.

- "Tehlikeli Yalnızlık: Ne Yurtta Ne de Dünyada Barış": Bu ilke ile aslında mevcut iktidarın izlediği dış politika ile devletin yalnızlaştığı, kimi komşularınca düşman olarak algılandığını ifade edilerek CHP'nin yurtta sulh cihanda sulh sözünün partinin en büyük hedefi olduğu belirtilmiştir.

- “Dünyaya Açık Dış Politika”: Dünyanın giderek çok kutuplu ve çok merkezli bir hale geldiği, bu nedenle dış politikanın tek değil çok taraflı olarak yürütülmesi gerektiği ifade edilmiştir (CHP, 2015a:194-198).

CHP izlemiş olduğu dış politikayı; "Türkiye'nin ulusal siyasi, ekonomik ve güvenlik çıkarlarını korumaya, bağımsızlı̆̆ını ve egemenliğini, ulusu ve ülkesiyle bölünmez bütünlüğ̈̈nü sürdürmeye, uluslararası saygınlığını ve etkinliğini arttırmaya yönelik barış̧̧ bir ulusal dış politika", olarak açıklamaktadır. 


\section{CUMHURIYET HALK PARTISİ VE FÍLISTIN İLIŞKISII}

\subsection{Türkiye Ortadoğu'da Nasıl Bir Rol Oynamalı?}

CHP'ye göre, Orta Doğu'da barış ve istikrarın sağlanması için ulus devlet anlayışının güçlendirilmesi, laik, demokratik ve çağdaş devlet anlayışının desteklenmesi gerekmektedir. Bölgedeki barış ve istikrarı sağlamanın en etkili yollarından biri demokrasiyi yaygınlaştırmaktır. Türkiye'nin laikliği anayasanın en temel ilkelerinden biri haline getirmesiyle gerçek bir demokrasiyi gerçekleştirdiğini ifade eden CHP, bu özelliği ile Türkiye'nin bölgede model olacağı kanısındadır (CHP, 2015b:132).

CHP'ye göre, Türkiye'nin Orta Doğu'da model ülke olması için yapılması gerekenler şu şekilde sıralanabilir:

- Komşularla ve bölge ülkeleriyle buyurgan olmayan ve karş1lıklı ilişkiler geliştirmeye dayanan kapsamlı ilişkiler inşa edilmeli,

- Laikliğe, kadın - erkek eşitliğine ve insan haklarına verilecek önemle Türkiye bölgesinde ilham kaynağ1 olan bir ülke olmall,

- Komşuların iç işlerine müdahale edilmeyerek, bağımsızlık, egemenlik ve toprak bütünlüklerine saygı duyulmalı,

- Orta Doğu'da demokratikleşme, basın özgürlüğü, kadın hakları ve sivil toplum alanlarındaki tüm ilerlemeler desteklenmeli (CHP, 2015a:204).

- Bölgemizdeki gerginlik, sorun ve çatışmaların çözümü için diplomasinin bütün olanaklarının kullanılması en iyi tercih olarak benimsenmeli.

- Uluslararası kuruluşlar ve büyük devletlerle ilişkilerin Orta Doğu'ya yönelik izlenen politikaları doğrudan etkilediğini bilinmektedir. Bu düşünceyle, başta $\mathrm{ABD}$ ve Rusya olmak üzere önde gelen ülkelerle uzun vadeli, eşitliğe, karşılıklı saygı ve birbirinin meşru çıkarlarını gözetmeye dayalı, geçici durumlara bağlı olmayan, kalıcı ve sürdürülebilir ilişkiler kurmalı. Ayrıca, BM ile diğer küresel ve bölgesel kuruluşların dünyada ve bölgemizde karşılaştı̆̆ımız sorunların çözümünde etkin rol oynamaları gerekli ve önemlidir (CHP, 2014:2).

\subsection{CHP'nin Filistin Sorununa Yaklaşımı}

CHP'ye göre, İsrail-Filistin sorununa Birleşmiş Milletler (BM) kararı çerçevesinde kalıcı bir çözüm bulunması için taraflarla görüşülmesi yöntemi benimsenmelidir (CHP, 2007:16). Orta Doğu ile bitişik bölgelerdeki istikrarsızlığın ve çalkantıların ana nedeni Filistin Sorunu 'dur. Filistin Sorunu'nun çözülmesi bölgeye barış ve istikrarı getireceği ifade edilmektedir (CHP, 2011:128-129). 2015 Seçim Bildirgesinde Orta Doğu'da Barış ve İstikrar başlığı altında İsrail-Filistin sorununa iki devlet esasına dayalı kalıcı bir çözüm bulmak için yapılan girişimlere destek olunacağı söylenmiştir (CHP, 2015a:204). Konuyla ilgili 2015 y1lı parti programında 2007 yılındaki seçim bildirgesinde geçen ifadeler aynı şekilde kullanılmıştır (CHP, 2015b:131).

Parti programlarında ve seçim bildirgelerinde Filistin sorununa sınırlı yer veren CHP, tarihsel süreçte siyasi destek vermiştir. Filistin Kurtuluş Örgütü'nün Ankara'da temsilcilik açması 1979 yılında Ecevit Hükümeti döneminde olmuştur (http://www.yenisafak.com/arsiv/2006/subat/19/izdusum.html). Yine 30 Ocak 1997 y1lında Oslo'da imzalanan El Halil (Hebron)'de Geçici Uluslararası Mevcudiyet Kurulması Hakkında Anlayış Muhtırası1'na göre; Hebron (El-Halil)'un Filistin Ulusal Yönetimi'ne devrinden sonra uluslararası gözlemcilik görevini üstlenmek üzere Türkiye, Danimarka, İtalya, İsveç, İsviçre ve Norveç tarafından 180 kişilik bir TIPH ${ }^{2}$ oluşturulmuştur (TBMM, 1997a). Bu anlaşmanın konuşulduğu meclis toplantısında CHP grubu adına konuşan CHP milletvekili Ali Dinçer yapılan anlaşmaya verdikleri desteği şu ifadelerle dile getirmiştir (TBMM Tutanak Dergisi, 1997:99):

\section{"Türkiye, bu göreve, hem Filistin Kurtuluş Örgütü hem de İsrail tarafindan davet edilmiştir. İslam} ülkeleri arasından sadece Türkiye çağrılmıştır. Filistinli kardeşlerimiz ve önderleri Yaser Arafat,

115 Ocak 1997 tarihinde İsrail ile Filistin Yönetimi arasında imzalanan El Halil Protokolüeene göre, İsrail, on gün içerisinde El Halile deki askerlerini çekecek ve şehrin belirlenen bazı bölgelerinde kontrol Filistinlilere geçecekti (Ertosun, 2012:190).

2 Temporary International Presence in Hebron (El Halileede Geçici Uluslararası Mevcudiyet) 
şahsen Türkiye'yi istemişlerdir. Müslümanlar için en önemli kutsal yerlerden biri olan El Halil'in, El Halil'deki El-Haramtil İbrahimî'nin; yani, Hazreti İbrahim Camiinin güvenliği için önce bize güvendiler. Bu, bizim için onurdur, yerine getirilmesi gereken ulusal bir görevdir, kutsal bir görevdir".

CHP milletvekili Ahmet Sırrı Özbek 20 Nisan 2004 tarihinde İsrail'in Filistin liderlerine karşı yapmış olduğu saldırılar hakkında TBMM'de yaptığı konuşmasında İsrail'in bu saldırılarını soykırım ve sistemli bir devlet terörü olarak değerlendirmiştir. Konuşmasının sonunda Filistin halkına verdiği desteğini "Mazlum Filistin halkına, emperyalizme ve siyonizme karşı olan mücadelelerinde başarılar diliyorum" sözleriyle ifade etmiştir (TBMM Tutanak Dergisi, 2004:70-71).

CHP genel başkanı Kemal Kılıçdaroğlu 2007 yılında "CHP, Filistin halkının haklı davasını kendi tarihi boyunca desteklemiştir bundan sonra da desteklemeye devam edecektir. CHP, Filistin Devletinin tanınmast çabasında Filistinli kardeşlerinin yanındadır" şeklinde bir açıklama yaparak Filistin'e desteğini dile getirmiştir (http://www.hurriyet.com.tr/mevlana-gibi-seslendi-gel-ne-olursan-ol-gel-4501053). 2012 yllında Kılıçdaroğlu Gazze'deki Filistin Hükümeti'nin Başbakanı İsmail Haniye ile görüşmüş “CHP'nin öteden beri bu ülkede kurtuluş savaşını vermiş insanların kurduğu bir parti olarak, Filistin'in mücadelesine destek olduğumuzu, Filistin'in BM'nin saygın bir üyesi olarak bağımsız bir devlet olarak yerini alması" isteğini ifade etmiştir (arsiv.chp.org.tr/?p=55419\&output=pdf).

Nisan 2016'da CHP Filistin'e bir heyet göndermiştir. Filistin'e giden grupta olan CHP genel başkan yardımcı Öztürk Yılmaz, Filistin Sorunu'nun Suriye, Irak ve IŞ่D'in gölgesinde kenara itildiğini söyleyerek Filistinlilere büyük bir sempati beslediklerini dile getirmiştir (https://www.chp.org.tr/Haberler/39/chp-heyeti-filistinde19438.aspx).

CHP gençlik kolları İsrail'in Filistin'e karşı saldırılarına karşı yürüyüş yaparak (www.gercekgundem.com), CHP Eskişehir Teşkilatı ise bir bildiri yayınlayarak (www.milliyet.com.tr) tepkilerini ortaya koymuşlardır. Filistin'e desteklerinin her zaman devam edeceğini ifade eden CHP, bu desteklerinin siyasi boyuttan öteye geçemediği görülmektedir. Nitekim 2010 yılında İsrail ablukasındaki Gazze'ye insani yardım götüren gemiye İsrail tarafından yapılan saldırıya ilişkin parti genel başkanı Kılıçdaroğlu Brookings Enstitüsü'nde “ $C H P$ 'nin Türkiye Vizyonu" başlıklı konferansta yaptığı konuşmasında CHP iktidarda olmuş olması halinde böyle bir olayın yaşanmamış olacağını ve durumun İsrail'in iç işlerine karışma olduğunu söylemiştir (www.erdogantoprak.com.tr).

\subsection{CHP'nin Türkiye'nin Filistin Sorunundaki Politikasına Yaklaşımı}

Genel olarak hükümetin Orta Doğu politikasını yanlış bulan CHP'ye göre, lider ve model olma iddiasında olan hükümet, Arap Baharı gibi temel bölgesel gelişmelerin dışında kalmıştır. Ayrıca CHP hükümetin izlediği dış politika ile Türkiye'nin Orta Doğu'daki bütün komşularıyla gergin ve risklerle dolu bir noktaya geldiğini savunmaktadır. Filistin Sorununda Türkiye'nin Filistin'de Hamas'1 desteklemesini doğru bulmayan CHP, bu politika yüzünden İsrail ile ilişkilerin zarar gördüğü ve diplomatik ilişkilerin koptuğu düşüncesindedir (CHP, 2014:5-6).

Türkiye'nin Filistin sorununda CHP, Türkiye'nin hem Filistin hem de İsrail'e eşit mesafede olması gerektiğini ve sorunun barış̧̧1 yollarla çözülmesi gerektiğine inanmaktadır. CHP genel başkan yardımcısı Öztürk Yılmaz da Filistin'e gerçekleştirdiği ziyaretinde partisinin iki devletli çözümü desteklediğini ifade etmiştir (https://www.chp.org.tr/Haberler/39/chp-heyeti-filistinde-19438.aspx).

\subsection{1. İsrail ile İkili İlişkiler}

Türkiye Filistin meselesinin siyasi olarak başlangıcını temsil eden İsrail devletinin kuruluşundan itibaren aslında olaya taraftır. Zira, kurulduğu zaman devleti ilk tanıyan Müslüman ülke, CHP iktidarındaki Türkiye olmuştur. İsrail'in tanınmasında CHP'nin dolayısıyla Türkiye'nin, kendisini Batı ile bütünleştiren ideolojik anlayışın rolü büyük olmuştur. Çünkü, bu aşamada Türkiye kendisini kuruluşundan itibaren yabancılaştırdığı Ortadoğu toplumlarının konuya yaklaşımı yerine, Batılı toplumların yaklaşımını benimsemiştir. CHP'nin başlangıçta takındığı bu tavır günümüze kadar duruşunda etkili olmuştur.

İkili ilişkiler kapsamında eski CHP Genel Başkanı ve SHP ve CHP milletvekilliği yapan Hikmet Çetin'in 1993 yılında İsrail'i ziyaret eden ilk Dış̧işleri Bakanı olması (www.sabah.com.tr) ve eski CHP Genel Başkanı Deniz Baykal'ın 2005 yılında İsrail'i ziyaret ederek Sosyalist Enternasyonal toplantısına katılması 
(http://www.haber7.com) ikili ilişkilerin devam ettirilmesi ve geliştirilmesinde önemli etkileri olan gelişmelerdir.

Genel olarak ikili ilişkileri iyi tutmaya çalışan CHP dönem dönem İsrail'e karşı tutumunu sertleştirerek İsrail'in Filistin'de yapmış olduğu saldırıları kınamak için meclise bildiri sunmuştur (Özcan, 2005:100). CHP Genel Başkan Yardımcısı Veli Ağbaba ise Filistin'de yaşanan saldırılar sonunda “...Israil devleti bizim dostumuz değildir. İsrail halkı tabi ki bizim dostumuzdur. Bugün masum Filistinlileri katleden hiç kimse bizim dostumuz olamaz" şeklinde ifadeler kullanmıştır (https://www.chp.org.tr/Haberler/17/agbabadan-diyanet-isleribaskanina-sert-elestiri-isidle-ilgili-kirmizi-cizgin-var-mi-11735.aspx). Aynı șekilde İsrail'in saldırılarını protesto etmek için CHP milletvekilleri Adalet ve Kalkınma Partisi milletvekilleri ve halk ile birlikte İsrail Büyükelçiliği önünde toplanmışalrdır (www.bursadabugun.com).

$\mathrm{Bu}$ yaşanan gelişmelere rağmen CHP Genel Başkanı Kemal Kılıçdaroğlu İsrail ile ilişkilerin gelişmesine önem vermiş, yaptığı bir açıklamada İsrail ile ilişkileri bozmak, İsrail ile diplomatik bir çatışma süreci yaşamak istemediklerini ifade etmiştir (http://www.yenisafak.com/politika/chpden-akilalmaz-mavi-marmara-aciklamasi589380). Nitekim bu ilişkilerin devamı için Filistin'e giden heyet aynı zamanda İsrail heyeti ile de görüşmeler gerçekleştirmiştir (https://www.chp.org.tr/Haberler/39/chp-heyeti-filistinde-19438.aspx). Nisan ayındaki bu ziyarete katılan heyette olan CHP Genel Başkan Yardımcısı Öztürk Yılmaz, İsrail ile her zaman normalleşme taraftarı olduklarını dile getirmiştir. İsrail'deki tüm partilerle ilişki halinde olduklarını söyleyen Yılmaz, İsrail milli gününe katılan tek kişi olduğunu CHP olarak tarafgir bir politika yürütmediklerini ifade etmiştir (Ö.Yılmaz ile kişisel iletişim). Türkiye'nin Irak'ta, Suriye'de ve Mısır'da izlediği politikalarda başarısız olduğunu, mezhep ve etnik çatışmalara taraf olmakla Filistin'de de aynı şekilde başarısız olacağını ifade eden Yılmaz, Türkiye'nin sorunda tarafsız olması gerektiğini söylemiştir (Ö.Yılmaz ile kişisel iletişim).

CHP'nin attığı bu adımlara karşı Şalom Gazetesi Köşe Yazarı ve İsrail-Orta Doğu Uzmanı Karel Valansi ile yapılan görüşmede Türkiye'deki partilerin İsrail ile olan ilişkilerini yeterli bulup bulmadığı ve özellikle CHP'nin Türkiye ile İsrail arasında ilişkilerin geliştirilmesinde yeterli bir çabasının olup olmadığı sorulmuştur. Valansi düşüncesini;

"Türkiye'de hiç bir parti veya STK veya grup İsrail ile ilişsileri düzeltmek amacını, kaygısını taşımıyor. Davos ile başlayan Mavi Marmara ile dibe vuran süreçte de buna şahit olduk. İktidar kadar CHP de var olan İsrail düşmanlı̆̆ını iç politik güçlenme için kullandılar. Bu nedenle normalleşme ancak dış politik sebeplerle gerçekleşti ve yeniden üçüncü bir partiye, Hamas ve Gazze'ye endekslendi" şeklinde ifade etmiştir (K.Valansi ile kişisel iletişim).

CHP'nin Filistin sorununun çözümü için, Birleşmiş Milletlerin kararı çerçevesinde, bölgede hem Filistin hem de İsrail devletlerinin varlıklarını sürdürmesi ve Batı Kudüs'ün İsrail'in Başkenti olması gerektiği görüşünün yeterli olup olmadığının sorulduğu Valansi'ye göre;

"Öncelikle çözümün gerçekleşmesi için ve bunda rol almak için istekli olmalı. İ̧ politikada başarılı bir muhalefet sergileyemediğinden dış politikada da söz sahibi olabileceği bir duruşu olamıyor. Sorunun çözümü için sahaya inmeli ve bölgede iki devletli çözümün bugünün şartlarında, yukarda belirtilen normlarda geçerliliğinin pek olmadı̆̆ını kendisi gözlemlemeli. Her iki tarafla da yakın çalışma içinde olmall. Ve iki devletli çözümün önündeki engellerin ne olduğunu kavrayıp yaratıcı çözüm önerileri üretebilmeli''dir. Son olarak Valansi, CHP'nin Filistin ve İsrail'e heyet göndermesinin sorunun çözümünde olumlu ama yetersiz olduğunu ifade etmiştir (K.Valansi ile kişisel iletişim).

\subsubsection{Filistin Sorunun Nihai Çözümü}

Cumhuriyet Halk Partisi, sadece Filistin ya da sadece İsrail'in desteklendiği bir sürecin olmadığı, her iki devletinde içinde bulunduğu bir çözüm süreciyle bu sorunun biteceği görüşündedir. Ayrıca CHP, bölgede Bat1 Kudüs başkentli İsrail’in var olması gerektiğini savunmaktadır (Ö.Yılmaz ile kişisel iletişim).

Filistin sorunun çözümde devletlerarası yapılan görüşmelerin öneminin farkında olan CHP’ye göre Madrid görüşmelerinin son aşaması olan Oslo barış süreci de sorunun çözümünde önemli bir adım olmuştur. Oslo barış sürecini Quartet Yol Haritası'nın izlemesi Filistin ve İsrail arasında kopan ilişkilerin tekrar düzelmesine katkısı olmuştur. Gerek Oslo görüşmeleri gerek Quartet Yol Haritası her iki devlet arasındaki barışın çok uzun soluklu olmadığının bir göstergesi olmuştur. Bugün de gelinen noktada CHP her iki devlet arasında daha kalıcı çözümler oluşturulması gerektiğini savunmaktadır (Ö.Yılmaz ile kişisel iletişim). 
Gerek Filistin'de gerek Suriye'de gerekse diğer Ortadoğu ülkelerindeki direnişlerde mezhep ve etnik çatışmalara taraf olmayan CHP, Filistin sorununda ve Filistin halkının direnişinde de tarafgir bir politika izlememektedir. CHP olarak çatışmaya taraf olanlardan herhangi birini desteklemediklerini söyleyen Yılmaz, her iki devlete de eşit mesafede olduklarını ifade etmiş̧ir (Ö.Yılmaz ile kişisel iletişim).

Türkiye'nin de sorunun çözümünde her iki devlete eşit uzaklıkta olması gerektiğine inanan CHP, Türkiye'nin bölgedeki etnik ve mezhep gruplarının birini desteklemekle soruna katkı sağlanmayacağı, aksine Türkiye'nin bölgede başarısız olacağına inanmaktadır (Ö.Yılmaz ile kişisel iletişim).

\subsubsection{Partinin Filistinli Taraflara Karşı Tutumu}

CHP Filistin sorununun çözüm yolu olarak İsrail ile barışın sağlanması gerektiğini ifade etmektedir. Bu barışın sadece Filistin ya da İsrail'e değil aynı zamanda tüm Orta Doğu'ya barış ve huzur getireceği inancındadır. CHP sosyal demokrasiyi savunan El Fetih ile ilişkileri geçmişte olduğu gibi bugün de devam etmektedir (Ö.Yılmaz ile kişisel iletişim).

2007 seçim bildirgesinde iktidarın Orta Doğu'da başarısız olma sebebini Hamas Liderini Ankara'ya davet etmesine bağlayan CHP'ye göre (CHP, 2007:15); Filistin'de bütüncül yapı korunmalı, Hamas ve El Fetih bütüncül bir yapı oluşturmalıdır. Özellikle Mahmud Abbas ile ilişkilerin geliştirilmesi taraftarı olan CHP, Türkiye'nin geçmişten bu güne sürekli Filistin halkının yanında olduğunu ama son dönemlerde hükümetin Müslüman Kardeşler ile olan ilişkilerde dolayı El Fetih ile ilişkilerin kesildiğini savunmaktadır (Ö.Yılmaz ile kişisel iletişim).

Filistin ile siyasi ilişkileri geliştirmek ve Filistin'in yanında olduğunu göstermek amacıyla CHP Genel Başkanı Kemal Kılıçdaroğlu Filistin Devlet Başkanı Mahmud Abbas ile görüşmüş (www.cumhuriyet.com.tr), Nisan 2016 da ise CHP Filistin'e bir heyet göndermiştir (https://www.chp.org.tr/Haberler/39/chp-heyeti-filistinde19438.aspx).

\section{SONUÇ}

Araştırma bulgularına göre, 1982 darbesiyle kapatıldı̆̆ dönem haricinde neredeyse Cumhuriyetle yaşıt olan CHP gerek iktidar olduğu dönemler gerek muhalefet olduğu dönemlerde hep Türk Siyasi Hayatının önemli bir parçası olmuştur. Mecliste ikinci en büyük parti olan ve Türkiye'nin alacağı kararları etkileyebilme gücüne sahip CHP Filistin sorununun çözümünde de ciddi sorumluluk taşımaktadır. Yapılan açıklamalarda sorununun çözümü için hükümete her konuda destek olacaklarını ifade eden CHP'ye göre, bölgenin sorunlarının temelinde Filistin yatmaktadır. Orta Doğu'da sorunların çözümünde ise, ulus devlet anlayışının güçlendirilmesi, laik, demokratik ve çağdaş devlet anlayışııın gerekliliğine vurgu yapmaktadır. CHP bölgede barış ve istikrarı sağlamanın en etkili yollarından birinin demokrasinin yaygınlaştırılması olduğunu savunmaktadır.

Hem ülke olarak hem de parti olarak Filistin'e desteklerinin her zaman olduğunu, bundan sonra da devam edeceğini ifade eden CHP'nin Filistin sorununa yeterince eğilmediği, parti politikalarında gerektiği kadar yer vermediği ve soruna yeterince önem vermediği görülmektedir. Son dönemde Filistin'e yapılan ziyaret olumlu olsa da yetersiz kalmış, görüşme dilek ve temenniden öteye gidememiştir. Partinin seçim bildirgelerinde ve parti programında sorununun yeterince dile getirilmemesi CHP'nin başka bir eksik durumu olarak görülmektedir.

Siyasi tarihi göz önüne alındığında CHP'nin ideolojik olarak kendisini nerede konumlandırması gerektiği konusunda sorunlar yaşadığı, aynı anlama gelen kavramlarla yer edinmeye çalıştı̆̆ görülmektedir. Bu ideolojik konumlandırmanın muhtevasına göre Partinin Filistin meselesinde takındı̆̆ı tavırda da sorunlar yaşanmaktadır. CHP'nin Cumhuriyet'i kuran parti olarak islam dünyası ile arasına mesafe koymaya çalışması, yaşanan sorunları çözmeye yakın durmamasına karşılık batıyla entegrasyonu savunması bir çelişki gibi durmakatadır. Aynı şekilde Filistin sorununda tarihten gelen önemli sorumluluklarının bulunduğu; buna karşılık bu sorumluluğunu yerine getirme konusunda yeterli aktif bir dış politika gütmemesi de ideolojik görüşleriyle çelişik durması bu araştırmanın tespitlerindendir. Zira CHP'ye göre, Türkiye Batı dünyasının bir parçasıdır ve bu çerçeveden BM'nin alacağı her türlü çözüm önerisine tam destek verilmesi gerekirken Türkiye'nin alacağı herhangi bir inisiyatif söz konusu olmamalıdır.

CHP'nin özellikle 1960'lı ve 1970'li yıllar arasında dünyada hakim olan sol rüzgardan etkilendiği ve parti içerisinde de sol ideolojinin hakim olduğu bir duruma geldiği ancak bunun parti tüzügüne tam anlamıyla yansımadığı görülmektedir. Buna ragmen, Filistin halkının haklı davasını üstlenen ve yürütmede önemli mesafeler kateden Filistin Kurtuluş Örğütü'nü ilk tanıyan ve Ankara'da büro açmasına imkan sağlayan CHP'dir. Bu haliyle tarihte üstlendiği anti-emperyalist misyon CHP'nin günümüzde başta Filistin sorunu olmak üzere 
giderek Ortadoğu halklarına yönelik aktif bir dış politikayı yüksek perdeden savunması gerekliliğini ortaya koymaktadır.

\section{KAYNAKÇA}

3821 sayılı 16.10.1981 tarih ve 2533 saylı Siyasî Partilerin Feshine Dair Kanunun Yürürlükten Kaldırılmasına ve 2820 Sayılı Siyasî Partiler Kanununda Değişiklik Yapılmasına İlişkin Kanun (03.07.1992 tarih ve 21273 sayll Resmi Gazete).

AKBALIK, Hakan (2006), “1946-1950 Döneminde Chp’nin Seçim Çalışmaları”, Yüksek Lisans Tezi, İnönü Üniversitesi Sosyal Bilimler Enstitüsü, Malatya.

ARMAĞAN, Servet (1967), "Türkiye'de Parlamento Seçimleri”, İstanbul Üniversitesi Hukuk Fakültesi Mecmuası, S.33(3-4), ss.45-100.

ATATÜRK ARAŞTIRMA MERKEZI (2006), Atatürk'ün Söylev ve Demeçleri I-III, Divan Yayıncılık, Ankara.

AYDIN, Mesut (2014), “Cumhurbaşkanlı̆̆ Arşivi Belgeleri Işı̆̆ında Müdafaa-i Hukuk Grubu'nun Kuruluşu ve Ülke Genelinde Gruba Ait Heyet-I Merkeziye Listelerinin Oluşturulmasl”, Turkish Studies, S.9(4), ss.97-137.

BİLA, Hikmet (1999), CHP 1919-1999, Doğan Kitap, İstanbul.

BOZDAĞLIOĞLU, Yücel (2003), Turkish Foreign Policy And Turkish Identity A Constructivist Approach, Taylor \& Francis Books, New York.

BURSADA BUGÜN GAZETESİ (2014), "Milletvekillerinden İsrail Eylemi”, E-Haber, http://www.bursadabugun.com/haber/tbmm-den-israil-in-filistin-e-saldirisina-sert-tepki-438891.html (Erişim Tarihi: 27.03.2018).

CHP (1923), Cumhuriyet Halk Partisi Tüzüğü, CHP Yayını, Ankara.

CHP (2004); Cumhuriyet Halk Partisinin Eğitim El Kitabı, CHP Yayını, Ankara, https://www.tbmm.gov.tr/develop/owa/e_yayin.eser_bilgi_q?ptip=SIYASI\%20PARTI\%20YAYINLARI \&pdemirbas $=200400296$ (Erişim Tarihi: 28.03.2018).

CHP (2007), 2007 Seçim Bildirgesi, CHP Yayını, Ankara, https://www.chp.org.tr/yayinlar/secim-bildirgeleri (Erişim Tarihi: 01.04.2018).

CHP (2011), 2011 Seçim Bildirgesi, CHP Yayını, Ankara, https://www.chp.org.tr/yayinlar/secim-bildirgeleri (Erişim Tarihi: 01.04.2018).

CHP (2012), “CHP Genel Başkanı Kemal Kılıçdaroğlu’nun İsmail Haniye ile Görüşmesi”, E-Haber, arsiv.chp.org.tr/?p=55419\&output=pdf (Erişim Tarihi: 28.03.2018).

CHP (2014), CHP ve AKP'nin Orta Doğu Politikalarının Ana Hatları, CHP Yayını, Ankara.

CHP (2015), “CHP Tarihi”, E-Haber, https://www.chp.org.tr/haberler/chp-tarihi (Erişim Tarihi: 27.03.2018).

CHP (2015a), 2015 Seçim Bildirgesi, CHP Yayını, Ankara, https://www.chp.org.tr/yayinlar/secim-bildirgeleri (Erişim Tarihi: 01.04.2018).

CHP (2015b), Cumhuriyet Halk Partisi Programı, CHP Yayını, Ankara.

CHP (2016), “CHP Genel Başkan Yardımcısı ve Malatya Milletvekili Veli Ağbaba'nın Basın Açıklaması”, E-Haber, https://www.chp.org.tr/Haberler/17/agbabadan-diyanet-isleri-baskaninasert-elestiri-isidle-ilgili-kirmizi-cizgin-var-mi-11735.aspx (Erişim Tarihi: 02.04.2018).

CHP (2016), “CHP'nin Filistin'e Heyet Göndermesi”, E-Haber, https://www.chp.org.tr/Haberler/39/chpheyeti-filistinde-19438.aspx (Erişim Tarihi: 11.04.2018).

$\begin{array}{ccccc}\text { CNNTÜRK } & \text { (2010), } & \text { Kapatılmasl”, } & \text { EHPin } & \text { E-Haber, } \\ \text { http://www.cnnturk.com/2010/turkiye/05/22/chpnin.kurultaylar.tarihi/577149.0/ } & \text { (Erisim } & \text { Tarihi: }\end{array}$ 09.04.2018). 
CUMHURIYET GAZETESI (2011), “CHP Genel Başkanı Kemal Kıllçdaroğlu’nun Filistin Devlet Başkanı Mahmud Abbas ile Görüşmesi”, E-Haber, http://www.cumhuriyet.com.tr/haber/diger/307010/Kilicdaroglu_Abbas_ile_gorustu.html (Erişim Tarihi: 04.04.2018).

ÇELIK, Orhan (2004), “1980 Sonrası CHP'de İdeoloji Değişimleri”, Yüksek Lisans Tezi, Mimar Sinan Güzel Sanatlar Üniversitesi Sosyal Bilimler Enstitüsü, İstanbul.

DERİNDERE, M. Nihat (1999), "Meşrutiyet Döneminde Seçimler ve Meclis-i Mebusan", E-Makale, http://www.koprudergisi.com/index.asp?Bolum=EskiSayilar\&Goster=Yazi\&YaziNo=412， (Erişim Tarihi:25.03.2018).

EMRE, Yunus (2013), CHP, Sosyal Demokrasi ve Sol, İletişim Yayınları, İstanbul.

GERÇEK GÜNDEM GAZETESİ (2014), “CHP’li Gençlerden Filistin Açılaması”, E-Haber, http://www.gercekgundem.com/siyaset/57495/chpli-genclerden-filistin-aciklamasi (Erişim Tarihi: 28.03.2018).

GÜVENÇ, Nazım (2002), Yine, Yeni, Yeniden CHP, Anahtar Kitaplar Yayınevi, İstanbul.

HABER7 (2005), "Deniz Baykal'in İsrail Ziyareti”, E-Haber, http://www.haber7.com/siyaset/haber/93023-deniz-baykal-israile-gitti (Erişim Tarihi: 27.03.2018).

HÜRRIYET GAZETESI (2006), “Deniz Baykal'in Konuşması”, E-Haber, http://www.hurriyet.com.tr/mevlana-gibi-seslendi-gel-ne-olursan-ol-gel-4501053 (Erişim Tarihi: 27.03.2018).

HÜRRIYET GAZETESİ (2011), “CHP Genel Başkanı Kemal Kılıçdaroğlu’nun Filistin Hakkında Açıklaması”, E-Haber, http://www.hurriyet.com.tr/kilicdaroglu-chp-filistinin-yaninda-18832007 (Erişim Tarihi: 28.03.2018).

KILIÇ, Fahri (2011), "Bolu Müdâfaa-İ Hukuk Cemiyeti ve Faaliyetleri”, AİBÜ Eğitim Fakültesi Üniversitesi Dergisi, S.11(1), ss.29-37.

KILIÇ, Oğuzhan Altuğ (2006), “1946’dan 1950’ye Geçişte Cumhuriyet Halk Partisi’nin İdeolojik Pozisyonunda Değişikler”, Yüksek Lisans Tezi, Gazi Üniversitesi Sosyal Bilimler Enstitüsü, Ankara.

KUMAŞ, Rahmi (1999), CHP'nin Soyağacı, Çağdaş Yayınları, İstanbul.

KÜLTÜREL YAPILANMA GRUBU (t.y.), “12 Eylül Belgeleri”, E-Dosya, https://docplayer.biz.tr/193471Kulturel-yapilanma-grubu-yorumsuz-12-eylul-belgeleri.html (Erişim Tarihi: 01.04.2018).

MILLIYET GAZETESI (08.05.1972), “CHP 5.Olağanüstü Kurultay Sonuçları”, E-Haber, http://gazetearsivi.milliyet.com.tr/ (Erişim Tarihi: 01.04.2018).

MILLIYET GAZETESİ (09.05.1972), “İsmet İnönü’nün CHP Genel Başkanlı̆̆ından İstifa Etmesi”, E-Haber, http://gazetearsivi.milliyet.com.tr/ (Erişim Tarihi: 29.03.2018).

MILLIYET GAZETESI (15.05.1972), “CHP Genel Başkanı'nın Bülent Ecevit'in Olması”, E-Haber, http://gazetearsivi.milliyet.com.tr/ (Erişim Tarihi: 29.03.2018).

MILLIYET GAZETESİ (2014), “CHP'den Filistin Halkına Destek Bildirisi”, E-Haber, http://www.milliyet.com.tr/chp-den-filistin-halkina-destek-bildirisi-eskisehir-yerelhaber-312115 (Erişim Tarihi: 28.03.2018).

MILLIYET GAZETESİ (22.03.1971), “CHP Genel Sekreteri Bülent Ecevit'in İstifası”, E-Haber, http://gazetearsivi.milliyet.com.tr/ (Erişim Tarihi: 29.03.2018).

MILLIYET GAZETESI (31.10.1980), “Bülent Ecevit'in CHP Genel Başkanlı̆̆ından İstifa Etmesi”, E-Haber, http://gazetearsivi.milliyet.com.tr/ (Erişim Tarihi: 01.04.2018).

ÖNKAŞ, Hasan (2006), “1980 Sonrası Türkiye’de Sosyal Demokrasi: CHP Örneği”, Yüksek Lisans Tezi, Muğla Üniversitesi Sosyal Bilimler Enstitüsü, Muğla.

ÖRMECI, Ozan (2012), “CHP'nin İdeolojik Evreleri ve Geleceğì”, E-Makale, http://ydemokrat.blogspot.com.tr/2012/01/chpnin-ideolojik-evreleri-ve-gelecegi.html (Erişim Tarihi: 30.03.2018). 
ÖVÜR, Mahmut (2011), 12 Eylül'den 12 Haziran'a Siyasi Partiler: Cumhuriyet Halk Partisi (CHP), Seta Analiz Yayınları, Ankara.

ÖZCAN, Gencer (2005), Türkiye-İsrail İlişkilerinde Dönüşüm: Güvenliğin Ötesi, Türkiye Ekonomik ve Sosyal Etüdler Vakfi Yayını, İstanbul.

SABAH GAZETESİ (2011), "Dışişleri Bakanı Hikmet Çetin'in İsrail Ziyareti”, E-Haber, https://www.sabah.com.tr/amerika/2011/09/07/turkiye-ve-israil-nereden-nereye (Erişim Tarihi: 03.04.2018).

SANDER, Oral (1998), Türkiye'nin Dış Politikası, İmge Yayınevi, İstanbul.

T. C. BAKANLAR KURULU (1949), 3/8942 sayılı İsrail Devletinin Derhal Tanınması Hakkında Bakanlar Kurulu Kararı (01.04.1949 tarih ve 7171 sayılı Resmi Gazete).

TBMM (1997), “Tutanak Dergisi”, Dönem:20, Cilt:21, Yasama Y111:2, Ankara.

TBMM (1997a), "Türkiye Tarafindan Hebron (El-Halil)'a Askeri Personel Gönderilmesi Hususunda Hükümetin Yetkili Kılınması İçin, Anayasanın 92 nci Maddesine Göre İzin Verilmesine Dair", 20.02.1997 Tarih ve 487 Sayılı Parlamento Kararı (22.02.1997 tarih ve 22913 sayılı Resmi Gazete).

TBMM (2004), “Tutanak Dergisi”, Dönem:22, Cilt:47, Yasama Y111:2, Ankara.

TOPRAK, Erdoğan (2013), “CHP Genel Başkanı Kemal Kılıçdaroğlu'nun Brookings Enstitüsü’nde CHP’nin Türkiye Vizyonu Başlıkll Konferansta Yaptı̆̆ Konuşması", E-Haber, http://www.erdogantoprak.com.tr/yhaber.asp?haberid=141336 (Erişim Tarihi: 02.04.2018).

TUNCER, Erol (2012), 1961 Seçimleri, Toplumsal Ekonomik Siyasal Araştırmalar Vakfı Yayını, Ankara.

YENI ŞAFAK GAZETESI (2006), “Filistin Kurtuluş Örgütü'nün Ankara'da Temsilcilik Açması”, E-Haber, http://www.yenisafak.com/arsiv/2006/subat/19/izdusum.html (Erişim Tarihi: 28.03.2018).

YENİ ŞAFAK GAZETESİ (2013), “CHP Genel Başkanı Kemal Kılıçdaroğlu’nun İsrail Hakkında Açılaması”, E-Haber, http://www.yenisafak.com/politika/chpden-akilalmaz-mavi-marmara-aciklamasi589380 (Erişim Tarihi: 28.03.2018).

YÜKSEK SEÇIM KURULU (t.y.), 1950 ve 1961 Seçim Sonuçları, YSK Yayını, Ankara, http://www.ysk.gov.tr/tr/1950-1977-yillari-arasi-milletvekili-genel-secimleri/3007 (Erişim Tarihi: 03.04.2018).

ZENGINOĞLU, Samet (2012), “Dörtlü Takrir: Amacl, İçeriği, Neticesi”, E-Makale, http://akademikperspektif.com/2012/06/07/dortlu-takrir-amaci-icerigi-neticesi/ (Erişim Tarihi: 29.03.2018).

\section{Kişisel İletişimler/Görüşmeler:}

YILMAZ, Öztürk, CHP Genel Başkan Yardımcısı.

VALANSI, Karel, Şalom Gazetesi Köşe Yazarı ve İsrail-Orta Doğu Uzmanı. 